\title{
Could Advanced Glycation End Products Explain the Poor Response to Controlled Ovarian Hyperstimulation in Obese Women?
}

\author{
John J. Zhang ${ }^{1 *}$ and Zaher Merhi' ${ }^{2,3}$ \\ ${ }^{1}$ Reproductive Endocrinology and Infertility, New Hope Fertility Center, New York, USA \\ ${ }^{2}$ Department of Obstetrics and Gynecology, Division of Reproductive Biology, New York, USA \\ ${ }^{3}$ University School of Medicine, New York, USA
}

Received: April 04, 2016; Accepted: April 27, 2016; Published: May 06, 2016

*Corresponding author: John J. Zhang, Reproductive Endocrinology and Infertility, New Hope Fertility Center, 4 Columbus Avenue, Fourth Floor, New York, USA, Tel: +212-517-7676; Fax: +212-489-6294; E-mail: johnzhang211@gmail.com

\begin{abstract}
Obesity, a worldwide pandemic, adversely impacts ovarian function. The pro-inflammatory Advanced Glycation End Products (AGEs) and their cell membrane Receptors for AGEs (RAGE) are elevated in the serum and tissues of obese women, respectively. Recent data have shown that AGEs contribute to alterations in the ovarian microenvironment. This review presents and summarizes important clinical and experimental studies pertaining to the role of the AGE-RAGE system in obesity-related ovarian dysfunction. It also discusses the role of the anti-inflammatory soluble Receptor for AGEs (sRAGE) in ovarian function and its changes in obesity and following unhealthy dietary habits. Data to date demonstrated that the AGE-RAGE system affects granulosa cell function and oocyte meiosis. Follicular fluid AGEs and sRAGE have been related to in vitro fertilization outcome. Thus data suggest that obesity-related alterations in the AGE-RAGE system and changes in circulating sRAGE level could potentially compromise ovarian response to controlled ovarian hyperstimulation and could adversely impact oocyte competence and ultimately fertility outcome. Finally, there is a critical need to unveil the mechanistic actions of the AGE-RAGE system at the level of the oocyte and its surrounding granulosa and theca cells in order to better improve ovarian response to controlled ovarian hyperstimulation in obese women.
\end{abstract}

Keywords: Advanced glycation end products; RAGE; sRAGE; obesity; controlled ovarian hyperstimulation; IVF

\section{Introduction}

Obesity is clearly becoming a worldwide pandemic and is now considered a disease that recent data have shown it affects more than one third of the adult population in the United States [1]. Obesity affects female reproduction [2-6] since compelling data showed that obese women are more predisposed to subfertility [7], have increased risk of miscarriages [8] and are more prone to having pregnancy complications such as gestational diabetes and preeclampsia [9]. As for subfertility, obese women are more predisposed to anovulation [7], have longer time to spontaneous conception [10,11] compared to normal-weight women. As far as outcome of assisted reproductive technology, obese women undergoing Controlled Ovarian Hyperstimulation $(\mathrm{COH})$ require higher doses of gonadotropins (whether or not due to fat distribution is still controversial). Thus, serum concentrations of gonadotropins have been shown to be inversely correlated to body weight because the pharmacokinetics of the medication is affected by adiposity [12]. For example, corifollitropin alfa is approved as a $100 \mu \mathrm{g}$ dosage for patients weighing $\leq 60 \mathrm{~kg}$ and as a $150 \mu \mathrm{g}$ dosage for patients weighing $>60 \mathrm{~kg}$ in women < 36 years of age [12]. Although controversial [13], we and others have shown that obese women have poorer IVF outcome as represented by the number of oocytes retrieved and number of mature oocytes $[14,15]$, poorer fertilization and implantation rates, and lower clinical pregnancy rates and live birth rates [16]. Recently, we have demonstrated that in conventional IVF, but not in minimal stimulation IVF, the number of total oocytes retrieved and MII oocytes were significantly lower in obese compared with normal BMI women [15]. This suggests that female adiposity might impair oocyte number and maturity in conventional IVF but not in minimal stimulation IVF and that mild ovarian stimulation might yield healthier oocytes in obese women. Additionally, several studies, including ours, have shown that obese women have significantly lower ovarian reserve as represented by serum Anti-Mullerian Hormone (AMH) levels-one of the best markers of ovarian reserve--compared to normalweight women $[3,14,17]$. On the other hand, an elevated serum AMH level and/or high Antral Follicle Count (AFC) by ultrasound can predict exaggerated ovarian response and ultimately ovarian achange with weight as compared to serum AMH [21].

Advanced Glycation End Products (AGEs) are highly reactive pro-inflammatory molecules that have been shown to play a pathogenic role in obesity and its adverse outcomes [22-27]. AGEs are the products of a chemical reaction called Maillard reaction in which the carbonyl group of carbohydrates reacts 
non-enzymatically with amino groups of proteins [28,29]. They constitute a heterogeneous group of compounds of more than 20 members, such as N-carboxymethyl-lysine (CML), pentosidine,1,2-dicarbonyl precursor compounds glyoxal, and methylglyoxal. They play a role in the pathogenesis of type 2 diabetes mellitus, cardiovascular disease, inflammation, obesity, aging, and reproduction [22,23,25,26,30-33]. We and others have demonstrated that the AGE system is involved in ovarian dysfunction and potentially obesity-related ovarian alterations $[6,22-27,34,35]$. The purpose of this article is to underline and call attention to AGEs as potential molecules that could explain some of the mechanisms involved in obesity-related ovarian dysfunction. The review will provide mechanistic information regarding the pathogenesis of ovulatory dysfunction in obesity that could support the development of new therapeutic agents, such as AGE blockers, as a novel strategy to treat and/or prevent ovarian dysfunction in obese women.

\section{AGEs and their Two Receptors RAGE and sRAGE}

AGEs are physiologically formed by a non-enzymatic modification of proteins and lipids by carbohydrates [24,3638]. Advanced glycation results in irreversible cross-linking of proteins, and loss of protein structure and function $[37,39,40]$. AGEs are formed slowly under physiological conditions but they form at accelerated rate in pathologic states such as diabetes, oxidative stress, aging, and obesity [28,30,32,41-43]. Once formed, they damage cellular structures via a number of mechanisms $[24,36]$. Pentosidine and CML are well characterized AGEs and have been used as markers of AGE accumulation in various bodily tissues $[23,34,44]$. AGEs play a pivotal role in the pathogenesis of cardiovascular disease [45-47] and more recently, obesity-related ovarian dysfuntion [6,27]. They can be either the trigger or the result of oxidative stress [35]. After their formation, AGEs are transported to diverse tissues via the circulation where they cause cellular damage by a number of different mechanisms. In one mechanism, AGEs can damage cellular structures via formation of cross-links between molecules in the basement membrane of the extracellular matrix e.g., collagen $[23,24,36]$. In another mechanism, the interaction of AGEs with their pro-inflammatory cell membrane receptor RAGE induces inflammation and apoptosis while the circulating sRAGE acts as decoy by binding the circulating AGEs and preventing AGE-RAGE interaction, thus conferring an anti-inflammatory role (Figure 1) $[23,24,36]$.

In addition to RAGE and SRAGE, AGEs bind to a multitude of receptors such as CD36, lectin-like oxidized low-density lipoprotein receptor-1, and macrophage scavenger receptors [48-52]. Interestingly, RAGE is not solely a receptor for AGEs but is a multi-ligand member of the immunoglobulin superfamily [5355]. RAGE is activated by many members of the proinflammatory S100/ calgranulin family, amyloid fibrils, amphoterins, and High Mobility Group Box 1 (HMGB1) [56]--molecules known to induce pro-inflammatory cytokines [57]. RAGE is expressed in several tissues such as heart, lung, eye, immune cells, mammary gland, pancreas, stomach, prostate, endothelial cells, embryonic tissue, testis, and ovary [39]. This receptor is composed of

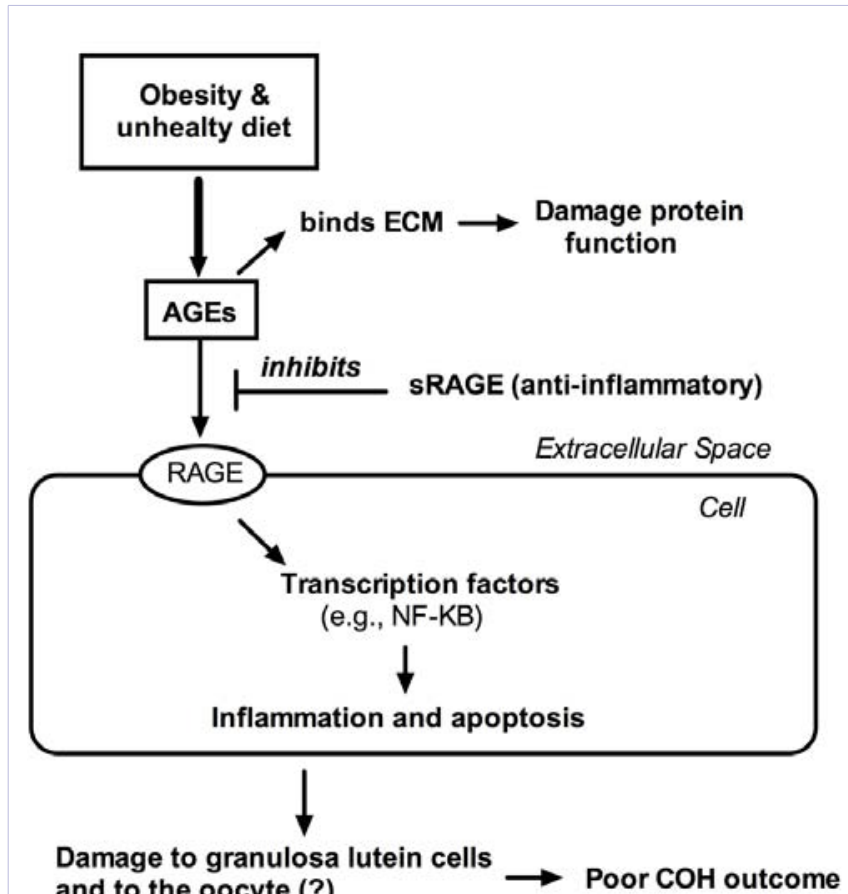

Figure 1: Obesity and unhealthy diet increases the levels of systemic AGEs. The interaction of AGEs with their receptor RAGE results in the generation of oxidative stress and activation of pro-inflammatory transcription factors such as Nuclear Factor kappa-B (NF- $\kappa$ B) leading to inflammation and apoptosis. AGEs could also bind to the Extracellular Matrix (ECM) causing tissue damage. The sRAGE receptor prevents the ligand AGEs from binding to their pro-inflammatory receptor RAGE. $\mathrm{COH}$ : Controlled Ovarian Hyperstimulation.

an extracellular region containing one " $\mathrm{V}$ "-type and two " $\mathrm{C}$ "type immunoglobulin domains [39]. In healthy adults, RAGE is expressed at a low basal level in the tissues. The up-regulation of RAGE has been associated with diverse pathological events, such as diabetes, atherosclerosis and others [58]. RAGE activates several signaling cascades with significant and wide-ranging impact on inflammatory and apoptotic gene expression profiles, such as activation of the transcription factor nuclear factorkappa B (NF-kB) (Figure 1) [59]. Furthermore, activation of RAGE induces a positive feedback loop by upregulating its own expression [59].

In addition to its full-length and membrane-bound form RAGE, a number of isoforms of RAGE have been identified $[60,61]$. In particular, RAGE has been shown to exist in a soluble isoform termed sRAGE that contains the same V-type and C-type regions found in RAGE but it lacks the transmembrane and cytosolic domains $[60,61]$. Consequently, sRAGE is found in the extracellular space and is capable of binding AGEs prior to their interaction with RAGE $[27,60,61]$. The sRAGE receptor is produced primarily by two mechanisms: a) from the cleaving actions of ADAM10 and MMPs on cell surface RAGE [62,63] or b) alternatively spliced pre-mRNA form of the receptor known as endogenous sRAGE $[64,65]$. Studies in animals have illustrated largely beneficial effects in reducing vascular and inflammatory 
stress and, thereby, preventing long-term tissue damage in models of diabetes and inflammatory disorders $[66,67]$.

\section{Unhealthy Diet, as Exogenous Source of AGEs, can Affect Ovarian Function}

In addition to AGEs that form within the body, AGEs also exist in food. AGEs are naturally present in uncooked animal-derived foods, and cooking results in the formation of more AGEs within these foods $[68,69]$. In particular, grilling, broiling, roasting, searing, and frying accelerate the formation of new AGEs $[68,69]$. Dietary patterns have clearly shifted in the past decade especially in the Western countries and they now contain high levels of refined starches, sugar, saturated fats, and omega- 6 fatty acids [70]. Dietary patterns high in refined starches, sugar, and saturated and trans-fatty acids, and poor in natural antioxidants and fiber from fruits, vegetables, and whole grains, and omega-3 fatty acids could cause activation of the immune system leading to excessive production of proinflammatory cytokines and reduced production of anti-inflammatory cytokines [70].

After the ingestion of an unhealthy diet, AGEs can get absorbed in the gastrointestinal tract $[42,71]$ and then get deposited in various tissues including the ovaries. Approximately $10 \%$ of the ingested AGEs are transported into circulation: one third of which is excreted by the kidneys while two-thirds linger in the body and bind to several tissues [72]. In rats, a study demonstrated that a high-AGE diet increased serum levels of AGEs and upregulated ovarian RAGE [34]; an effect that was reversed by the ingestion of a low-AGE diet, the administration of an AGE blocker [73-75], the use of weight loss medication such as orlistat [76], and even exercise [77]. Additionally, a study by Diamanti-Kandarakis, et al. showed that long term consumption of AGEs was associated with higher levels of fasting glucose, insulin and serum AGEs, as well as increased AGEs localization and RAGE staining in rat ovarian tissue [34]. Interestingly, diet-induced weight loss has been shown to increase serum sRAGE levels $[26,78]$, and higher baseline sRAGE was associated with better weight loss outcome following bariatric surgery [79].

\section{Obesity is an Inflammatory State Characterized by Alterations in the AGE-RAGE System}

Obesity is a state of chronic inflammation characterized by elevated systemic AGEs [27,80]. Adiposity is associated with increased "pro-inflammatory" M1 macrophage accumulation in the adipose tissue [81]. Hence, in obesity, the adipose tissue is said to be "M1 polarized" [82]. The AGE-RAGE system plays an important role in modulating systemic inflammation $[25,42,83]$. Circulating AGEs have been shown to correlate with as C-Reactive Protein (CRP) and other oxidative stress markers $[42,83,84]$ and induce tissue injury $[83,85]$. In humans, dietary AGE restriction reduced plasma levels of CRP, Tumor Necrosis Factor- $\alpha$ (TNF- $\alpha$ ), and vascular cell adhesion molecule-1 $[84,86]$.

AGEs are linked to adiposity [27,28]. In rats, AGEs stimulate adipogenesis by uregulating Akt signaling pathway [87], an action that was reversed by the AGE breaker alagebrium and by Akt inhibitor [87]. A recent study measured the effects of various mouse diets containing high- or low-AGEs in the presence of highor low-fat content on mouse weight and epididymal fat pads [88]. That study reported a significant difference in weight gain and epididymal fat pad weights in mice that received the combination diet "high-AGE and high-fat" [88]. The authors also demonstrated that leptin, TNF- $\alpha$, interleukin-6, and myeloperoxidase levels were significantly higher in the combination "high-AGE and highfat" group [88]. The authors concluded that a diet containing high AGEs in the presence of high fat induces weight gain in mice. High-fat diet induces peripheral inflammation and weight gain in a RAGE-dependent manner [25]. In one study [22], C57BL/6 RAGE -/- mice was provided a high-fat diet to induce obesity and they showed upregulation of RAGE. In another study [25], mice provided a high-fat diet induced expression of the RAGE ligand HMGB1 and CML epitopes in liver and adipose tissue [25]. Genetic deficiency of RAGE prevented the effects of high-fat diet on weight gain and adipose tissue inflammation [25].

We and others have shown that plasma levels of the antiinflammatory sRAGE were inversely correlated with BMI [89]. sRAGE levels were shown to be significantly reduced in obese women compared to normal-weight women [26] and shortterm weight loss program led to a significant increase in plasma sRAGE levels [26]. We recently demonstrated that sRAGE levels were negatively correlated with BMI in 31 reproductive-aged women $(r=-0.5, p<0.001)$ [27]. The lower levels of sRAGE in the obese women might indicate that the intraovarian levels of AGEs exert an exaggerated effect at the level of the oocyte thus altering the molecular and energetic reserve that are needed to sustain normal meiosis in the oocyte [35]. Interestingly, caloric restriction induced weight loss increased serum sRAGE levels by approximately $150 \%$ [90] and sRAGE is expressed by inflammatory cells, such as monocytes and macrophages [91] and its production reduced systemic inflammation [92-97].

\section{Controlled Ovarian Hyperstimulation in Obese Women and the AGE System}

Although infertility associated with obesity may be partly attributed to changes in the endometrial gene expression at the time of implantation [98], studies suggested that oocyte quantity and quality is also an important factor in obese women trying to conceive via assisted reproductive technology [99]. Hence, the mechanisms by which obesity causes ovarian dysfunction and poor conception rates are not completely understood. Obesityrelated anovulation has been well documented to occur due to a defect in luteinizing hormone (LH) pulsatility [100]. Although infertility associated with obesity has been related to anovulation [7], data have shown that the time to spontaneous pregnancy is significantly longer in obese women even in those who have regular menstrual cycles [10-11]. Despite data pertaining to obesity and IVF success from individual centers is controversial [101-103], data from large national studies showed that, obese women undergoing $\mathrm{COH}$ with oocyte retrieval for IVF have significantly worse outcomes compared to normal-weight women [104-105].

Because AGEs are elevated in obese women, it is important 
to assess the effect of AGEs on oocyte competency during $\mathrm{COH}$ for IVF. AGEs contribute to perturbations of the ovarian microenvironment leading to lower fertility status [35]. Diamanti-Kandarakis, et al. [106] demonstrated that human glycated albumin, used as a source of AGEs in vitro, interferes with LH action in human KGN granulosa cells by causing a sustained activation of the ERK1/2 pathway which is critical for normal folliculogenesis and ultimately ovulation. Additionally, Piperi, et al. [107] demonstrated that human glycated albumin inhibited the insulin-mediated Akt phosphorylation and significantly reduced GLUT-4 levels (glucose transporters) on KGN cell membrane [107]. In that study, human glycated albumin also significantly reduced GLUT-4 translocation to the cell membrane when added to insulin in vitro. Since the competency of the oocyte is highly influenced by glucose intracellular action inside the cumulus oocyte complex and the follicular fluid [108], these findings indicate that AGEs could alter folliculogenesis and ultimately ovulation. AGEs have been shown to induce meiotic delay/arrest in mouse oocyte [109], as represented by spindle aberrations, chromosomal misalignment, abnormal chromatin condensation, more chromosomal lagging, changes in mitochondrial distribution, and altered inner-mitochondrial glutathione redox potential [109]. All these functions are critical for oocyte fertilization and embryo development.

Literature from assisted reproduction technology studies partly elucidated the impact of AGEs on $\mathrm{COH}$ outcome. One study [110] demonstrated that higher levels of AGEs in the follicular fluid and the serum negatively correlated with follicular growth and oocyte fertilization, indication diminished fertility. Another study [111] reported a borderline positive correlation between follicular fluid sRAGE and the number of oocytes retrieved following $\mathrm{COH}$ for IVF. We examined the relationship between follicular fluid sRAGE and follicular fluid AMH levels which is one of the best marker of ovarian reserve in women undergoing $\mathrm{COH}$ [112]. Our results indicated that follicular fluid sRAGE predicted the number of oocytes retrieved (after adjusting for age, BMI, day $3 \mathrm{FSH}$ and dose of gonadotropins), and positively correlated with follicular fluid AMH levels. Our study thus suggested that the antiinflammatory sRAGE could represent a useful biological marker of the follicular environment in women undergoing $\mathrm{COH}$.

We [112] and others [110,111,113] have studied the role of the AGE-RAGE system in fertility. One study [114] demonstrated that AGE-modified proteins are present on the surface of freshly isolated human granulosa lutein cells collected from women who underwent $\mathrm{COH}$. This suggests that granulosa lutein cells are exposed to AGE-related damage in vivo. That study also observed that granulosa cells and ovarian monocytes bind AGE-modified albumin in vitro and that specific RAGE receptors are present on the surface of these cells [114]. These data imply that AGEs may also be involved in the decline of ovarian function and thus might lead to poorer response to $\mathrm{COH}$ in women with elevated AGEs, such as obese women.

Jinno, et al. [110] measured the levels of toxic AGEs in the blood and the follicular fluid of patients who underwent $\mathrm{COH}$ for IVF. They demonstrated that the accumulation of toxic AGEs in follicular fluid and serum negatively correlated with follicular growth, oocyte fertilization, and embryonic development. Lower concentrations of AGEs in follicular fluid and lower concentration of AGEs in serum were the most significant predictors for achievement of ongoing pregnancy (independently from age and ovarian reserve as reflected by day $3 \mathrm{FSH}$ ). Again, these data indicate that there is a clinical evidence for an important role for AGEs in ovarian dysfunction and poorer $\mathrm{COH}$ outcome in women with elevated AGEs. Another study [113] reported a significant negative correlation between serum sRAGE levels and the number of growing follicles and retrieved oocytes following $\mathrm{COH}$. Women who got pregnant following $\mathrm{COH}$ showed significantly higher sRAGE levels in their follicular fluid compared to those who did not get pregnant.

We examined the relationship between follicular fluid sRAGE and measures of ovarian reserve as reflected by AMH [112]. We studied 34 women who underwent $\mathrm{COH}$ followed by oocyte retrieval for IVF and we collected cumulus granulosa cells after which AMH and its receptor (AMHR-II) mRNA expression were quantified by RT-PCR [115]. Our results showed that the higher the follicular fluid sRAGE, the lower the dose of gonadotropins needed per $\mathrm{COH}$ cycle (independent of age, BMI and day 3 FSH). Follicular fluid sRAGE was also positively correlated with the number of oocytes retrieved and follicular fluid AMH protein levels.

\section{Conclusion}

More than two thirds of the U.S. population is overweight or obese $[1,116]$. Presently, there is lack of targeted treatment for the costly obesity-related ovarian dysfunction that leads to poorer $\mathrm{COH}$ outcome for fertility treatments [117]. With respect to obese women seeking pregnancy, the use of fertility treatments including assisted reproductive technology are costly and frequently associated with poorer success in obese women compared to normal-weight women [105,117,118]. During the assisted reproductive technology process, obese women have a poorer response to gonadotropins thus requiring much higher doses of these expensive medications, produce fewer and poorer quality oocytes, generate poorer quality embryos, achieve lower pregnancy rates, and have higher miscarriage rates [119-122]. This review presents a background framework for a new hypothesis suggesting the involvement of AGEs and their receptors in $\mathrm{COH}$ in obese women. Since weight loss is commonly challenging and often not sustainable [123,124] with less than $20 \%$ of individuals achieving long-term weight maintenance $[125,126]$ there is a critical need to establish therapeutic strategies for obesity-related ovarian dysfunction in order to improve ovarian response to $\mathrm{COH}$. However, a major barrier to developing these therapies is a lack of understanding of the mechanisms underlying this poorer ovarian response to $\mathrm{COH}$ in obese women.

In the last decade, the dicarbonyl stress theory of ovarian dysfunction has gained a lot of attention. More accumulating evidence is indicating that AGEs could partly explain a mechanism for the obesity-related ovarian dysfunction. In addition to the 
usual ovarian reserve markers (such as $\mathrm{AMH}$, day $3 \mathrm{FSH}$ and sonographic antral follicle count), it is reasonable to postulate that a plasma level of AGEs and/or sRAGE could be helpful in predicting the ovarian response to $\mathrm{COH}$. Hypothetically, sRAGE could represent a potential therapeutic agent since data have shown that it is protective for ovarian follicles. Finally, the pathological significance of AGEs, these harmful proinflammatory molecules, in follicular health clearly requires further investigation and targeting AGEs via the development of effective and healthy AGE blockers could offer potential therapeutic options for the treatment of poor response to $\mathrm{COH}$ particularly in obese women.

\section{References}

1. Flegal KM, Carroll MD, Kit BK and Ogden CL. Prevalence of obesity and trends in the distribution of body mass index among US adults, 19992010. JAMA. 2012;307: 491-497. doi: 10.1001/jama.2012.39.

2. Pasquali R, Patton L and Gambineri A. Obesity and infertility. Curr Opin Endocrinol Diabetes Obes. 2007;14:482-487.

3. Merhi Z, Buyuk E, Berger DS, Zapantis A, Israel DD, Chua S Jr, et al Leptin suppresses anti-Mullerian hormone gene expression through the JAK2/STAT3 pathway in luteinized granulosa cells of women undergoing IVF. Hum Reprod. 2013;28(6):1661-9. doi: 10.1093/ humrep/det072.

4. Merhi ZO. Weight loss by bariatric surgery and subsequent fertility. Fertility and sterility. 2007;87:430-432.

5. Merhi ZO. Impact of bariatric surgery on female reproduction. Fertil Steril. 2009;92: 501-1508.

6. Merhi Z, McGee EA and Buyuk E. Role of advanced glycation endproducts in obesity-related ovarian dysfunction. Minerva Endocrinol. 2014;39(3):167-174.

7. Rich-Edwards JW, Spiegelman D, Garland M, Hertzmark E, Hunter D J, Colditz GA, et al. Physical activity, body mass index, and ovulatory disorder infertility. Epidemiology. 2002;13:184-190.

8. Boots C, Stephenson MD. Does obesity increase the risk of miscarriage in spontaneous conception: a systematic review? Semin Reprod Med 2011;29(6):507-13. doi: 10.1055/s-0031-1293204.

9. Marshall NE, Spong, CY. Obesity, pregnancy complications, and birth outcomes. Semin Reprod Med. 2012;30(6):465-71. doi: 10.1055/s0032-1328874.

10. Gesink Law DC, Maclehose RF, Longnecker MP. Obesity and time to pregnancy. Hum Reprod. 2007;22(2):414-20.

11. van der Steeg JW, Steures P, Eijkemans MJ, Habbema JD, Hompes PG, Burggraaff JM, et al. Obesity affects spontaneous pregnancy chances in subfertile, ovulatory women. Hum Reprod. 2008;23:324-328.

12.Zandvliet AS, Prohn M, de Greef R, van Aarle F, Sisk CM, Stegmann BJ. Impact of patient characteristics on the pharmacokinetics of corifollitropin alfa during controlled ovarian stimulation. Br J Clin Pharmacol. 2016. doi: 10.1111/bcp.12939.

13. Legge A, Bouzayen R, Hamilton L, Young D. The impact of maternal body mass index on in vitro fertilization outcomes. J Obstet Gynaecol Can. 2014;36(7):613-9.

14. Buyuk E, Seifer DB, Illions E, Grazi RV, Lieman H. Elevated body mass index is associated with lower serum anti-mullerian hormone levels in infertile women with diminished ovarian reserve but not with normal ovarian reserve. Fertil Steril. 2011;95(7):2364-8. doi: 10.1016/j. fertnstert.2011.03.081.

15.Zhang JJ, Feret M, Chang L, Yang M, Merhi Z. Obesity adversely impacts the number and maturity of oocytes in conventional IVF not in minimal stimulation IVF. Gynecol Endocrinol. 2015;31(5):409-13. doi: 10.3109/09513590.2015.1014785.

16. Tamer Erel C, Senturk LM. The impact of body mass index on assisted reproduction. Curr Opin Obstet Gynecol. 2009;21(3):228-35. doi: 10.1097/GCO.0b013e32832aee96.

17. Steiner AZ, Stanczyk FZ, Patel S, Edelman A. Antimullerian hormone and obesity: insights in oral contraceptive users. Contraception. 2010;81(3):245-8. doi: 10.1016/j.contraception.2009.10.004.

18. Martins WP, Kollmann M, Raine-Fenning, N. Counting ovarian follicles: updated threshold for diagnosis of hyperandrogenic anovulation. Ultrasound Obstet Gynecol. 2014;44(2):131-4. doi: 10.1002/ uog.13402.

19. Lima ML, Martins WP, Coelho Neto MA, Nastri CO, Ferriani RA, Navarro PA. Assessment of ovarian reserve by antral follicle count in ovaries with endometrioma. Ultrasound Obstet Gynecol. 2015;46(2):239-42. doi: 10.1002/uog.14763.

20. Nastri CO, Teixeira DM, Moroni RM, Leitão VM, Martins WP. Ovarian hyperstimulation syndrome: pathophysiology, staging, prediction and prevention. Ultrasound in obstetrics \& gynecology: the official journal of the International Society of Ultrasound in Obstetrics and Gynecology. 2015;45:377-393. doi: 10.1002/uog.14684.

21. Su HI, Sammel MD, Freeman EW, Lin H, DeBlasis T, Gracia CR. Body size affects measures of ovarian reserve in late reproductive age women. Menopause. 2008;15(5):857-61. doi: 10.1097/ gme.0b013e318165981e.

22. Leuner B, Max M, Thamm K, Kausler C, Yakobus Y, Bierhaus A. RAGE influences obesity in mice. Effects of the presence of RAGE on weight gain, AGE accumulation, and insulin levels in mice on a high fat diet. Z Gerontol Geriatr. 2012;45(2):102-8. doi: 10.1007/s00391-0110279-x.

23. Merhi Z. Advanced glycation end products and their relevance in female reproduction. Hum Reprod. 2014;29(1):135-45. doi: 10.1093/ humrep/det383.

24.Piperi C, Adamopoulos C, Dalagiorgou, G, Diamanti-Kandarakis, E, and Papavassiliou AG. Crosstalk between advanced glycation and endoplasmic reticulum stress: emerging therapeutic targeting for metabolic diseases. J Clin Endocrinol Metab. 2012;97(7):2231-42. doi: 10.1210/jc.2011-3408.

25. Song F, Hurtado del Pozo C, Rosario R, Zou YS, Ananthakrishnan R, $\mathrm{Xu}$ X, Patel PR. RAGE Regulates the Metabolic and Inflammatory Response to High Fat Feeding in Mice. Diabetes. 2014;63(6):1948-65. doi: $10.2337 / \mathrm{db} 13-1636$

26. Vazzana N, Guagnano MT, Cuccurullo C, Ferrante E, Lattanzio S, Liani R. Endogenous secretory RAGE in obese women: association with platelet activation and oxidative stress. J Clin Endocrinol Metab. 2012;97(9):E1726-30. doi: 10.1210/jc.2012-1473.

27. Merhi Z, Irani M, Doswell AD, Ambroggio J. Follicular fluid soluble receptor for advanced glycation end-products (sRAGE): a potential indicator of ovarian reserve. J Clin Endocrinol Metab. 2014;99(2):E22633. doi: 10.1210/jc.2013-3839.

28. Unoki H, Yamagishi S. Advanced glycation end products and insulin resistance. C Curr Pharm Des. 2008;14(10):987-9. 
29. Brownlee M, Cerami A, Vlassara H. Advanced glycosylation end products in tissue and the biochemical basis of diabetic complications. N Engl J Med. 1988;318(20):1315-21.

30. Yamagishi S, NakamuraK, Imaizumi T. Advanced glycation end products (AGEs) and diabetic vascular complications. Curr Diabetes Rev. 2005;1(1):93-106.

31. Diamanti-Kandarakis E, Piperi C, Patsouris E, Korkolopoulou P, Panidis D, Pawelczyk L. Immunohistochemical localization of advanced glycation end-products (AGEs) and their receptor (RAGE) in polycystic and normal ovaries. Histochem Cell Biol. 2007;127(6):5819.

32. Tatone C, Amicarelli F. The aging ovary-the poor granulosa cells. Fertil Steril. 2013;99(1):12-7. doi: 10.1016/j.fertnstert.2012.11.029.

33. Park JH, Choi TS. Polycystic ovary syndrome (PCOS)-like phenotypes in the d-galactose-induced aging mouse model. Biochem Biophys Res Commun. 2012;427(4):701-4. doi: 10.1016/j.bbrc.2012.09.099.

34.Diamanti-Kandarakis E, Piperi C, Korkolopoulou P, Kandaraki E Levidou G, Papalois A, et al. Accumulation of dietary glycotoxins in the reproductive system of normal female rats. J Mol Med (Berl). 2007;85(12):1413-20.

35. Tatone C, Eichenlaub-Ritter U, Amicarelli F. Dicarbonyl stress and glyoxalases in ovarian function. Biochem Soc Trans 42, 433-438. Biochem Soc Trans. 2014;42(2):433-8. doi: 10.1042/BST20140023.

36. Inagi R. Inhibitors of advanced glycation and endoplasmic reticulum stress. Methods Enzymol. 2011;491:361-80. doi: 10.1016/B978-0-12385928-0.00020-1.

37. Monnier VM, Sell DR. Prevention and repair of protein damage by the Maillard reaction in vivo. Rejuvenation Res 9, 264-273.

38. Roszyk L, Faye B, Sapin V, Somda F, Tauveron I. Glycated haemoglobin (HbA1c): today and tomorrow. Ann Endocrinol (Paris). 2007;68(5):357-65.

39. Basta G. Receptor for advanced glycation endproducts and atherosclerosis: From basic mechanisms to clinical implications. Atherosclerosis. 2008;196(1):9-21.

40. Lander HM, Tauras JM, Ogiste JS, Hori O, Moss RA, Schmidt AM. Activation of the receptor for advanced glycation end products triggers a p21(ras)-dependent mitogen-activated protein kinase pathway regulated by oxidant stress. J Biol Chem. 1997;272(28):17810-4.

41. Takahashi M, Oikawa M, Nagano A. Effect of age and menopause on serum concentrations of pentosidine, an advanced glycation end product. J Gerontol A Biol Sci Med Sci. 2000;55(3):M137-40.

42. Uribarri J, Cai W, Peppa M, Goodman S, Ferrucci L, Striker G, Vlassara H. Circulating glycotoxins and dietary advanced glycation endproducts: two links to inflammatory response, oxidative stress, and aging. J Gerontol A Biol Sci Med Sci. 2007;62(4):427-33.

43. Yan SF, D'Agati V, Schmidt AM, Ramasamy R. Receptor for Advanced Glycation Endproducts (RAGE): a formidable force in the pathogenesis of the cardiovascular complications of diabetes \& aging. Curr Mol Med. 2007;7(8):699-710.

44. Desai K, Wu L. Methylglyoxal and advanced glycation endproducts: new therapeutic horizons? Recent Pat Cardiovasc Drug Discov. 2007;2(2):89-99.

45. Fukushima Y, Daida H, Morimoto T, Kasai T, Miyauchi K, Yamagishi S, Takeuchi M. Relationship between Advanced Glycation End Products and Plaque Progression in Patients with Acute Coronary Syndrome: The JAPAN-ACS Sub-study. Cardiovasc Diabetol. 2013;12:5. doi: 10.1186/1475-2840-12-5.
46. Daffu G, del Pozo CH, O’Shea KM, Ananthakrishnan R, Ramasamy $\mathrm{R}$, Schmidt AM. Radical roles for RAGE in the pathogenesis of oxidative stress in cardiovascular diseases and beyond. Int J Mol Sci. 2013;14(10):19891-910. doi: 10.3390/ijms141019891.

47. Yan SF, Ramasamy R, Schmidt AM. The receptor for advanced glycation endproducts (RAGE) and cardiovascular disease. Expert Rev Mol Med. 2009;11:e9. doi: 10.1017/S146239940900101X.

48. Ramasamy R, Yan SF, Schmidt AM. The diverse ligand repertoire of the receptor for advanced glycation endproducts and pathways to the complications of diabetes. Vascul Pharmacol. 2012;57(5-6):160-7. doi: 10.1016/j.vph.2012.06.004.

49. Ohgami N, Nagai R, Ikemoto M, Arai H, Kuniyasu A, Horiuchi S. Cd36, a member of the class b scavenger receptor family, as a receptor for advanced glycation end products. Ann N Y Acad Sci. 2001;947:350-5.

50. Rudijanto A. The expression and down stream effect of lectin likeoxidized low density lipoprotein 1 (LOX-1) in hyperglycemic state Acta Med Indones. 2007;39(1):36-43.

51. Araki N, Higashi T, Mori T, Shibayama R, Kawabe Y, Kodama T, et al. Macrophage scavenger receptor mediates the endocytic uptake and degradation of advanced glycation end products of the Maillard reaction. Eur J Biochem. 1995;230(2):408-15.

52. Lai KN, Leung JC, Chan LY, Li FF, Tang SC, Lam MF, et al. Differential expression of receptors for advanced glycation end-products in peritoneal mesothelial cells exposed to glucose degradation products. Clin Exp Immunol. 138(3):466-475.

53. Wolf R, Howard OM, Dong HF, Voscopoulos C, Boeshans K, Winston J, et al. Chemotactic activity of S100A7 (Psoriasin) is mediated by the receptor for advanced glycation end products and potentiates inflammation with highly homologous but functionally distinct S100A15. J Immunol. 2008;181(2):1499-506.

54. Hofmann MA, Drury S, Fu C, Qu W, Taguchi A, Lu Y, et al. RAGE mediates a novel proinflammatory axis: a central cell surface receptor for $\mathrm{S} 100 /$ calgranulin polypeptides. Cell. 1999;97(7):889-901.

55. Hofmann MA, Drury S, Fu C, Qu W, Taguchi A, Lu Y, et al. S100A8 and S100A9 mediate endotoxin-induced cardiomyocyte dysfunction via the receptor for advanced glycation end products. Cell. 1999;97(7):889-901.

56. Taguchi A, Blood DC, del Toro G, Canet A, Lee DC, Qu W, et al. Blockade of RAGE-amphoterin signalling suppresses tumour growth and metastases. Nature. 2000;405(6784):354-60.

57. Clynes R, Moser B, Yan SF, Ramasamy R, Herold K, Schmidt AM, Clynes, et al. Receptor for AGE (RAGE): weaving tangled webs within the inflammatory response. Curr Mol Med. 2007;7(8):743-51.

58. Schmidt AM,Yan SD, Wautier JL, Stern D. Activation of receptor for advanced glycation end products: a mechanism for chronic vascular dysfunction in diabetic vasculopathy and atherosclerosis. Circ Res. 1999;84(5):489-97.

59. Kalea AZ, Schmidt AM, Hudson BI. RAGE: a novel biological and genetic marker for vascular disease. Clin Sci (Lond). 2009;116(8):621-37. Doi: 10.1042/CS20080494.

60. Dunaif A. Insulin resistance in PCOS. Endocr Rev. 1997;(6):774-800

61. Diamanti-Kandarakis E, Piperi C, Kalofoutis A, Creatsas G. Increased levels of serum advanced glycation end-products in women with polycystic ovary syndrome. Clin Endocrinol (Oxf). 2005;62(1):37-43.

62. Raucci A, Cugusi S, Antonelli A, Barabino SM, Monti L, Bierhaus A, et al. A soluble form of the receptor for advanced glycation endproducts 
(RAGE) is produced by proteolytic cleavage of the membrane-bound form by the sheddase a disintegrin and metalloprotease 10 (ADAM10). FASEB J. 2008;22(10):3716-27. doi: 10.1096/fj.08-109033.

63. Zhang L, Bukulin M, Kojro E, Roth A, Metz VV, Fahrenholz F, et al. Receptor for advanced glycation end products is subjected to protein ectodomain shedding by metalloproteinases. J Biol Chem. 2008;283(51):35507-16. doi: 10.1074/jbc.M806948200.

64. Hudson BI1, Carter AM, Harja E, Kalea AZ, Arriero M, Yang H, et al. Identification, classification, and expression of RAGE gene splice variants. FASEB J. 2008 May;22(5):1572-80.

65. Yonekura H, Yamamoto Y, Sakurai S, Petrova RG, Abedin MJ, Li H, et al. Novel splice variants of the receptor for advanced glycation endproducts expressed in human vascular endothelial cells and pericytes, and their putative roles in diabetes-induced vascular injury. Biochem J. 2003;370(Pt 3):1097-109.

66. Nakamura K, Yamagishi S, Adachi H, Matsui T, Kurita-Nakamura Y, Takeuchi M, et al. Circulating advanced glycation end products (AGEs) and soluble form of receptor for AGEs (sRAGE) are independent determinants of serum monocyte chemoattractant protein-1 (MCP-1) levels in patients with type 2 diabetes. Diabetes Metab Res Rev. 2008 (2):109-14

67. Nakamura K, Yamagishi S, Adachi H, Kurita-Nakamura Y, Matsui T, et al. Yoshida T Serum levels of sRAGE, the soluble form of receptor for advanced glycation end products, are associated with inflammatory markers in patients with type 2 diabetes. Mol Med. 2007(3-4):185-9.

68. O'Brien J, Morrissey PA. Nutritional and toxicological aspects of the Maillard browning reaction in foods. Crit Rev Food Sci Nutr. 1989;(3):211-48

69. Goldberg T1, Cai W, Peppa M, Dardaine V, Baliga BS, Uribarri J, et al. Advanced glycoxidation end products in commonly consumed foods. J Am Diet Assoc. 2004;104(8):1287-91.

70.Giugliano D, Ceriello A, Esposito K. The effects of diet on inflammation: emphasis on the metabolic syndrome. J Am Coll Cardiol. 2006;48(4):677-85

71.Uribarri J, Cai W, Woodward M, Tripp E, Goldberg L, Pyzik, et al. Elevated serum advanced glycation endproducts in obese indicate risk for the metabolic syndrome: a link between healthy and unhealthy obesity? J Clin Endocrinol Metab. 2015;100(5):1957-66. doi: 10.1210/ jc.2014-3925

72. Koschinsky T, He CJ, Mitsuhashi T, Bucala R, Liu C, Buenting C, et al. Orally absorbed reactive glycation products (glycotoxins): an environmental risk factor in diabetic nephropathy. Proc Natl Acad Sci U S A. 1997;94(12):6474-9.

73. Uribarri J, Peppa M, Cai W, Goldberg T, Lu M, He C, et al. Restriction of dietary glycotoxins reduces excessive advanced glycation end products in renal failure patients. J Am Soc Nephrol. 2003(3):728-31.

74. He C, Sabol J, Mitsuhashi T, Vlassara H. Dietary glycotoxins: inhibition of reactive products by aminoguanidine facilitates renal clearance and reduces tissue sequestration. Diabetes. 1999;48(6):1308-15.

75. Diamanti-Kandarakis E, Alexandraki K, Piperi C, Aessopos A, Paterakis T, Katsikis I, et al. Effect of metformin administration on plasma advanced glycation end product levels in women with polycystic ovary syndrome. Metabolism. 2007;56(1):129-34.

76. Diamanti-Kandarakis E, Katsikis I, Piperi C, Alexandraki K, Panidis D. Effect of long-term orlistat treatment on serum levels of advanced glycation end-products in women with polycystic ovary syndrome. Clin Endocrinol (Oxf). 2007;66(1):103-9.
77. Boor P, Celec P, Behuliak M, Grancic P, Kebis A, Kukan M, et al. Regular moderate exercise reduces advanced glycation and ameliorates early diabetic nephropathy in obese Zucker rats. Metabolism. 2009;58(11):1669-77. doi: 10.1016/j.metabol.2009.05.025.

78. Hagen I, Schulte DM, Müller N, Martinsen J, Türk K, Hedderich J, et al. Soluble receptor for advanced glycation end products as a potential biomarker to predict weight loss and improvement of insulin sensitivity by a very low calorie diet of obese human subjects. Cytokine. 2015;73(2):265-9. doi: 10.1016/j.cyto.2015.02.022.

79. Parikh M, Chung M, Sheth S, McMacken M, Zahra T, Saunders JK, et al. Randomized pilot trial of bariatric surgery versus intensive medical weight management on diabetes remission in type 2 diabetic patients who do NOT meet NIH criteria for surgery and the role of soluble RAGE as a novel biomarker of success. Ann Surg. 2014;260(4):617-22; discussion 622-4. doi: 10.1097/SLA.0000000000000919.

80. Gregor MF, Hotamisligil GS. Inflammatory mechanisms in obesity. Annu Rev Immunol. 2011;29:415-45. doi: 10.1146/annurevimmunol-031210-101322.

81. Lumeng CN, Bodzin JL, Saltiel AR. Obesity induces a phenotypic switch in adipose tissue macrophage polarization. J Clin Invest. 2007;117(1):175-84.

82.Johnson AR, Milner JJ, Makowski L. The inflammation highway: metabolism accelerates inflammatory traffic in obesity. Immunol Rev. 2012;249(1):218-38. doi: 10.1111/j.1600-065X.2012.01151.x.

83. Vlassara H, Cai W, Crandall J, Goldberg T, Oberstein R, Dardaine V, et al. Inflammatory mediators are induced by dietary glycotoxins, a major risk factor for diabetic angiopathy. Proc Natl Acad Sci U S A. 2002;99(24):15596-601.

84.Luévano-Contreras C, Garay-Sevilla ME, Wrobel K, Malacara JM, Wrobel K. Dietary advanced glycation end products restriction diminishes inflammation markers and oxidative stress in patients with type 2 diabetes mellitus. J Clin Biochem Nutr. 2013;52(1):22-6. doi: $10.3164 /$ jcbn.12-40.

85. Negrean M, Stirban A, Stratmann B, Gawlowski T, Horstmann T, Götting C, et al. Effects of low- and high-advanced glycation endproduct meals on macro- and microvascular endothelial function and oxidative stress in patients with type 2 diabetes mellitus. Am J Clin Nutr. 2007;85(5):1236-43.

86. Uribarri J, Cai W, Ramdas M, Goodman S, Pyzik R, Chen X, et al. Restriction of advanced glycation end products improves insulin resistance in human type 2 diabetes: potential role of AGER1 and SIRT1. Diabetes Care. 2011;34(7):1610-6. doi: 10.2337/dc11-0091.

87. Jia X, Chang T, Wilson TW, Wu L. Methylglyoxal mediates adipocyte proliferation by increasing phosphorylation of Akt1. PLoS One. 2012;7(5):e36610. doi: 10.1371/journal.pone.0036610.

88. Sayej WN, Knight Iii PR, Guo WA, Mullan B, Ohtake PJ, Davidson BA, et al. Advanced Glycation End Products Induce Obesity and Hepatosteatosis in CD-1 Wild-Type Mice. Biomed Res Int. 2016;2016:7867852. doi: $10.1155 / 2016 / 7867852$.

89. Koyama H, Shoji T, Yokoyama H, Motoyama K, Mori K, Fukumoto $\mathrm{S}$, et al. Plasma level of endogenous secretory RAGE is associated with components of the metabolic syndrome and atherosclerosis. Arterioscler Thromb Vasc Biol. 2005;25(12):2587-93.

90. Brix JM, Höllerl F, Kopp HP, Schernthaner GH, Schernthaner G. The soluble form of the receptor of advanced glycation endproducts increases after bariatric surgery in morbid obesity. Int J Obes (Lond). 2012;36(11):1412-7. doi: 10.1038/ijo.2012.107. 
91. Cheng C, Tsuneyama K, Kominami R, Shinohara H, Sakurai S, Yonekura $\mathrm{H}$, et al. Expression profiling of endogenous secretory receptor for advanced glycation end products in human organs. Mod Pathol. 2005;18(10):1385-96.

92. Park L, Raman KG, Lee KJ, Lu Y, Ferran LJJr, Chow WS, et al. Suppression of accelerated diabetic atherosclerosis by the soluble receptor for advanced glycation endproducts. Nat Med. 1998;4(9):1025-31.

93. Bucciarelli LG, Wendt T, Qu W, Lu Y, Lalla E, Rong LL, et al RAGE blockade stabilizes established atherosclerosis in diabetic apolipoprotein E-null mice. Circulation. 2002;106(22):2827-35.

94. Basta G, Sironi AM, Lazzerini G, Del Turco S, Buzzigoli E, Casolaro A, et al. Circulating soluble receptor for advanced glycation end products is inversely associated with glycemic control and S100A12 protein. J Clin Endocrinol Metab. 2006;91(11):4628-34.

95. Choi KM, Han KA, Ahn HJ, Hwang SY, Hong HC, Choi HY, et al. Effects of exercise on sRAGE levels and cardiometabolic risk factors in patients with type 2 diabetes: a randomized controlled trial. J Clin Endocrinol Metab. 2012;97(10):3751-8. doi: 10.1210/jc.2012-1951.

96. Choi KM, Yoo HJ, Kim HY, Lee KW, Seo JA, Kim SG, et al. Association between endogenous secretory RAGE, inflammatory markers and arterial stiffness. International journal of cardiology 132, 96-101 Int J Cardiol. 2009 ;132(1):96-101. doi: 10.1016/j.ijcard.2007.10.047.

97. Marsche G, Weigle B, Sattler W, Malle E, Soluble RAGE blocks scavenger receptor CD36-mediated uptake of hypochlorite-modified low-density lipoprotein. FASEB journal : FASEB J. 2007;(12):3075-82

98. Bellver J, Martínez-Conejero JA, Labarta E, Alamá P, Melo MA, Remohí $\mathrm{J}$, et al. Endometrial gene expression in the window of implantation is altered in obese women especially in association with polycystic ovary syndrome. Fertil Steril. 2011;95(7):2335-41, 2341.e1-8. doi: 10.1016/j.fertnstert.2011.03.021.

99. Jungheim ES, Schon SB, Schulte MB, DeUgarte DA, Fowler SA, Tuuli MG, et al. IVF outcomes in obese donor oocyte recipients: Hum Reprod. 2013(10):2720-7. doi: 10.1093/humrep/det292.

100. Jain A, Polotsky AJ, Rochester D, Berga SL, Loucks T, Zeitlian G, et al. Pulsatile luteinizing hormone amplitude and progesterone metabolite excretion are reduced in obese women. J Clin Endocrinol Metab. 2007;92(7):2468-73

101. Ozekinci M, Seven A, Olgan S, Sakinci M, Keskin 5, Akar ME, et al Does obesity have detrimental effects on IVF treatment outcomes? BMC Womens Health. 2015;15:61. doi: 10.1186/s12905-0150223-0.

102. Comstock IA, Kim S, Behr B, Lathi RB, Increased body mass index negatively impacts blastocyst formation rate in normal responders undergoing in vitro fertilization. JAssist Reprod Genet. 2015;32(9):1299-304. doi: 10.1007/s10815-015-0515-1.

103. Goldman KN, Hodes-WertzB, McCulloh DH, Flom JD, Grifo JA Association of body mass index with embryonic aneuploidy. Fertil Steril;103(3):744-8. doi: 10.1016/j.fertnstert.2014.11.029.

104. Kupka MS, Gnoth C, Buehler K, Dahncke W, Kruessel JS. Impact of female and male obesity on IVF/ICSI: results of 700,000 ARTcycles in Germany. Gynecol Endocrinol. 2011(3):144-9. doi: 10.3109/09513590.2010.487617.

105. Luke B, Brown MB, Missmer SA, Bukulmez O, Leach R, Stern JE, et al. The effect of increasing obesity on the response to and outcome of assisted reproductive technology: a national study. Fertil Steril. 2011;96(4):820-5. doi: 10.1016/j.fertnstert.2011.07.1100.
106. Diamanti-Kandarakis EPC, Livadas S, Kandaraki E, PapageorgiouE, Koutsilieris M. Interference of AGE-RAGE signaling with steroidogenic enzyme action in human ovarian cells. Endocrine Society. San Francisco, CA: 2013.

107. Piperi CPE, Koutsilieris M, Diamanti-Kandarakis E. Advanced Glycation End-products inhibit insulin signaling in human granulosa cells: a causative link to PCOS pathogenesis. Endocrine Society. San Francisco, CA: 2013.

108. Sutton-McDowall ML, Gilchrist RB, Thompson JG. The pivotal role of glucose metabolism in determining oocyte developmental competence. Reproduction. 2010;139(4):685-95. doi: 10.1530/ REP-09-0345.

109. Tatone C, Heizenrieder T, Di Emidio G, Treffon P, Amicarelli F, Seidel T, et al. Evidence that carbonyl stress by methylglyoxal exposure induces DNA damage and spindle aberrations, affects mitochondrial integrity in mammalian oocytes and contributes to oocyte ageing. Hum Reprod. 2011(7):1843-59. doi: 10.1093/ humrep/der140.

110. Jinno M, Takeuchi M, Watanabe A, Teruya K, Hirohama J, Eguchi N, et al. Advanced glycation end-products accumulation compromises embryonic development and achievement of pregnancy by assisted reproductive technology. Hum Reprod. 2011(3):604-10. doi: 10.1093/humrep/deq388.

111. Fujii EY, Nakayama M. The measurements of RAGE, VEGF, and AGEs in the plasma and follicular fluid of reproductive women: the influence of aging. Fertil Steril. 2010 Jul;94(2):694-700. doi: 10.1016/j.fertnstert.2009.03.029.

112. Merhi Z, Irani M, Doswell AD, Ambroggio J. Soluble receptor for advanced glycation end-products (sRAGE): A potential indicator of ovarian reserve. J Clin Endocrinol Metab. 2014;99(2):E226-33. doi: 10.1210/jc.2013-3839.

113. Malicková K, Jarosová R, Rezábek K, Fait T, Masata J, Janatková I, et al. Concentrations of sRAGE in serum and follicular fluid in assisted reproductive cycles--a preliminary study. Clin Lab. 2010;56(910):377-84.

114. Stensen MH, Tanbo T, Storeng R, Fedorcsak P. Advanced glycation end products and their receptor contribute to ovarian ageing. Human reproduction (Oxford, England) 29, 125-134.

115. Jayaprakasan K, Campbell B, Hopkisson J, Johnson I, Raine-Fenning N. A prospective, comparative analysis of anti-Mullerian hormone, inhibin-B, and three-dimensional ultrasound determinants of ovarian reserve in the prediction of poor response to controlled ovarian stimulation. Fertil Steril. 2010;93(3):855-64.doi: 10.1016/j. fertnstert.2008.10.042.

116. Cheryl D, Fryar MSPH, Margaret D, Carroll MSPH, Cynthia L. Prevalence of Overweight, Obesity, and Extreme Obesity Among Adults: United States, 1960-1962 Through 2011-2012. National Center for Health Statistics. 2014. Available from: http://www.cdc. gov/nchs/data/hestat/obesity_adult_11_12/obesity_adult_11_12. pdf.

117. Koning AM, Kuchenbecker WK, Groen H, Hoek A, Land JA, Khan KS, et al. Economic consequences of overweight and obesity in infertility: a framework for evaluating the costs and outcomes of fertility care. Hum Reprod Update. 2010;16(3):246-54. doi: 10.1093/humupd/dmp053.

118. Rittenberg V, Seshadri S, Sunkara SK, Sobaleva S, Oteng-Ntim E, El-Toukhy T, Effect of body mass index on IVF treatment outcome: an updated systematic review and meta-analysis. Reprod Biomed Online. 2011(4):421-39. doi: 10.1016/j.rbmo.2011.06.018. 
119. Leary C, Leese HJ, Sturmey RG3. Human embryos from overweight and obese women display phenotypic and metabolic abnormalities Hum Reprod. 2015(1):122-32. doi: 10.1093/humrep/deu276.

120. Zhang D, Zhu Y, Gao H, Zhou B, Zhang R, Wang T, et al. Overweight and obesity negatively affect the outcomes of ovarian stimulation and in vitro fertilisation: a cohort study of 2628 Chinese women. Gynecol Endocrinol. 2015(5):325-32. doi: 10.3109/09513591003632100.

121. Jungheim ES1, Lanzendorf SE, Odem RR, Moley KH, Chang AS, Ratts VS, et al. Morbid obesity is associated with lower clinical pregnancy rates after in vitro fertilization in women with polycystic ovary syndrome. Fertil Steril. 2009 Jul;92(1):256-61. doi: 10.1016/j. fertnstert.2008.04.063.

122. Robker RL. Evidence that obesity alters the quality of oocytes and embryos. Pathophysiology. 2008(2):115-21. doi: 10.1016/j pathophys.2008.04.004.
123. Wadden TA. Treatment of obesity by moderate and severe caloric restriction. Results of clinical research trials. Ann Intern Med. 1993;119(7 Pt 2):688-93.

124. Stubbs J, Whybrow S, Teixeira P, Blundell J, Lawton C, Westenhoefer J. Problems in identifying predictors and correlates of weight loss and maintenance: implications for weight control therapies based on behaviour change. Obes Rev. 2011;12(9):688-708. doi: 10.1111/j.1467-789X.2011.00883.x.

125. Wing RR, Phelan S. Long-term weight loss maintenance. Am J Clin Nutr. 2005;82(1 Suppl):222S-225S.

126. Rössner $S$, Hammarstrand $M$, Hemmingsson E, Neovius $M$, Johansson K. Long-term weight loss and weight-loss maintenance strategies. Obes Rev. 2008;9(6):624-30. doi: 10.1111/j.1467789X.2008.00516.x. 